\title{
Proximate composition and kinectics drying of sweet pine nuts compared to typical nuts of Araucaria angustifolia
}

\section{Bruna Valéria Gil ${ }^{1}$ Amanda Pacheco Cardoso Moura ${ }^{1}$ Marcos Robson Sachet $^{2}{ }^{\oplus}$

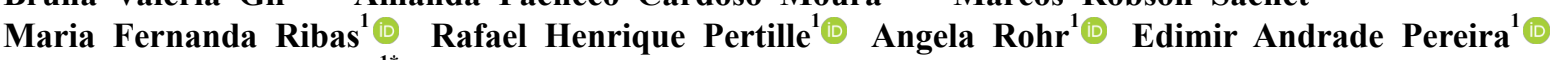 Moeses Andrigo Danner ${ }^{1 *}$}

\footnotetext{
${ }^{1}$ Universidade Tecnológica Federal do Paraná, Campus Pato Branco, Via do Conhecimento, 85503-390, Pato Branco, PR, Brasil. E-mail moesesdanner@utfpr.edu.br. "Corresponding author.

${ }^{2}$ Universidade Federal de Roraima, Campus Murupu, Boa Vista, RR, Brasil.

ABSTRACT: The objective of this research was to determine the proximate composition and kinetics drying of sweet pine nuts compared to typical pine nuts of Araucaria angustifolia. This study is based on the proximate components, color, and duration of pine nuts drying of both types, and the influence of temperature and cutting geometry on the dehydration process. Sweet pine nuts had lower calorific value and carbohydrate content, but higher lipid, dietary fiber, protein, and ash contents when compared to typical pine nuts. Color of sweet pine nuts is light pink whereas the typical pine nut is yellowish-white. Sweet pine nuts were also softer. Drying kinetics of the seeds fit well into the logistic and Thompson models. To accelerate drying rates, we recommend slicing pine nuts into thin cross-sections and drying them at temperatures of $60{ }^{\circ} \mathrm{C}$ for typical pine nuts and $70^{\circ} \mathrm{C}$ for sweet pine nuts.

Key words: brazilian pine, centesimal composition, gluten free flour, food drying.
}

Composição proximal e cinética de secagem de pinhões doces

e pinhões típicos de Araucaria angustifolia

RESUMO: O objetivo deste trabalho foi determinar a composição centesimal e a cinética de secagem de pinhões doces em comparação com pinhões típicos de Araucaria angustifolia. Este estudo baseia-se na composição centesimal, cor e duração da secagem dos pinhões de ambos os tipos e na influência da temperatura e da geometria de corte no processo de desidratação. Os pinhões doces apresentaram menor valor calorifico e conteúdo de carboidratos. Por outro lado, apresentaram maior teor de lipídios, fibras alimentares, proteinas e cinzas quando comparados aos pinhões típicos. A cor dos pinhões doces é rosa claro, enquanto o pinhão típico é branco amarelado. Os pinhões doces também são mais macios. A cinética de secagem das sementes se enquadra bem nos modelos logístico e de Thompson. Para acelerar as taxas de secagem, recomendamos fatiar os pinhões em seções finas e secá-los a temperaturas de $60^{\circ} \mathrm{C}$ para pinhões típicos e $70^{\circ} \mathrm{C}$ para pinhões doces.

Palavras-chave: pinheiro brasileiro, composição centesimal, farinha sem glúten, secagem de alimentos.

\section{INTRODUCTION}

The Araucaria angustifolia (Bertol. Kuntze), popularly known as Brazilian pine or Paraná pine, belongs to the Araucariaceae family and found in South America, predominantly in Brazil (WANG \& RAN, 2014). This species is considered critically endangered (IUCN 2018) mainly as a consequence of deforestation carried out between 1930 and 1970 (GUERRA et al., 2002). Therefore, incentivizing conservation through the use of pine nuts (Araucaria seed) as a food product can encourage reforestation and reduce extraction pressure on the remaining natural forest (DANNER et al., 2012).

Pine nuts have been one of the main sources of food for indigenous populations in Southern Brazil (BITENCOURT \& KRAUSPENHAR, 2006). Additionally, the pine nut has socioeconomic importance due to the commercialization of $A$. angustifolia and extraction of this plant from several areas where it naturally occurs (SHIBATA et al., 2016). The pine nut is consumed both cooked and 
roasted, mainly between April and July throughout the region (CORDENUNSI et al., 2004; COSTA et al., 2013). Pine nuts can also be used in the production of pasta and bread after being processed into flour (WASZCZYNSKYJ \& COSTA, 2014), or incorporated into fruit jams (BOLZAN \& PEREIRA, 2017).

The dry matter of pine nuts is mostly composed of starch, which, after dehydration, can be used as gluten-free flour, which has high potential for use in the food industry (CORDENUNSI et al., 2004; CONFORTI \& LUPANO, 2008). There is one Araucaria tree that produces pine nuts with higher sugar and lower starch content compared to typical pine nuts. These nuts have greater potential for commercialization and use in food products due to their sweet taste and soft texture (SACHET et al., 2020). Drying pine nuts enables them to be used in the production of food throughout the year. This resultin added value and increased consumption, as drying pine nuts facilitates transport, handling, and storage as well as increasing quality and shelf life. Additionally, it limits microbiological contamination and enzymatic and oxidative degradation (MATHLOUTHI, 2001; ERTEKIN \& FIRAT, 2017). Studies that define the ideal conditions for pine nut dehydration are necessary to increase the utility of this component in the food industry (ERTEKIN \& FIRAT, 2017).

The objective of this research was to determine the proximate composition and drying kinetics of sweet pine nuts compared to typical ones.

\section{MATERIALS AND METHODS}

An Araucaria tree characterized by its production of sweet seeds was found on a farm in Pato Branco, Paraná, Brazil (26²' $50^{\prime}$ ' S; 52 $38^{\circ} 42^{\prime}$ ' $\mathrm{W})$. Two pine cones were collected from this tree, and in the laboratory the pine nuts were manually peeled. Sweet and typical pine nuts were assessed by a taster who tasted a slice of each seed. Both kinds of nut were present in the same pine cone with an approximate 1:1 ratio (SACHET et al., 2020). Pine nuts were separated into two groups for proximate composition analysis as fresh pine nuts and pine nut flour. Pine nut flour was prepared in a rotary mill at $10,000 \mathrm{rpm}$, and the moisture of the samples was determined by the direct oven drying method at 105 $\pm 3{ }^{\circ} \mathrm{C}$ until a constant weight was attained $(\sim 24$ hours). The mineral residue (ash) was obtained by incineration of samples at $550{ }^{\circ} \mathrm{C}$. The quantification of lipids occurred by direct extraction in Soxhlet, using petroleum ether as a solvent (INSTITUTO
ADOLFO LUTZ, 2008). Protein content was determined by the Kjeldahl technique (TEDESCO et al., 1995). Total dietary fiber quantification was performed using the enzymatic-gravimetric method (MEGAZYME INTERNATIONAL IRELAND, 2016). Total carbohydrate content was calculated asper the formula [100 - (\% moisture $+\%$ ash + $\%$ protein $+\%$ lipid $+\%$ fiber $)]$, and available carbohydrate content was calculated by the difference between total carbohydrate content and fiber. Data analysis of the proximate composition variables was performed using the unpaired two-tailed t-test to compare the two types of pine nuts (typical and sweet) in the fresh and flour samples.

From a sample of 10 pine nuts (10 replicates) of each type, the parameters of coloration, $\mathrm{L}^{*}$ (luminosity), $\mathrm{C}^{*}$ (saturation) and $\mathrm{h}$ (hue angle of shade) were determined by the Konica Minolta colorimeter (model Chroma Meter CR-400, Japan). In the same samples, hardness was measured with the TA.XT Plus texturometer (Texture Analyzer Stable Micro System, Surrey, UK), fitted with a $2.0 \mathrm{~mm}$ diameter probe. The analysis was performed on three locations of the pine nuts, apex, center, and base, to verify if there was heterogeneity in the hardness along the seed. The color and hardness data were subjected to normality analysis of the distribution of errors through the Shapiro-Wilk test and the homogeneity of the treatment variance through the Bartlett test. Data that did not meet the assumptions were transformed by the Box-Cox procedure. Then, the two-way ANOVA analysis ( 2 x 3: pine nut type $\mathrm{x}$ seed location) was performed, followed by a comparison of means by the Tukey test $(\mathrm{p} \leq 0.05)$.

For the study of drying kinetics, each of the 54 typical pine nuts and 54 sweet pine nuts were cut in three distinct ways: 1) in 10 circular transverse slices, $\sim 4.0 \mathrm{~mm}$ thick; 2) in a longitudinal slice of the central part of the nut, $\sim 8.0 \mathrm{~mm}$ thick; and 3 ) in two longitudinal slices, $\sim 12.0 \mathrm{~mm}$ thick. Samples were weighed and distributed in aluminum trays with perforated bottoms and dried in a forcedair oven at three temperatures: 50,60 , or $70{ }^{\circ} \mathrm{C}$. Weight loss readings weremeasured until the samples reached equilibrium moisture, that is, until they reached a constant weight. Data were expressed as dimensionless moisture ratio $(\mathrm{RX})$ using the equation $R X=\frac{\mathrm{U}-\mathrm{U}_{\mathrm{e}}}{\mathrm{U}_{\mathrm{i}}-\mathrm{U}_{\mathrm{e}}}$

(dimensionless); $\mathrm{U}=$ water content of product at time $\mathrm{t}$ (decimal dry basis); $\mathrm{U}_{\mathrm{i}}$ : initial product water content (decimal dry basis); $\mathrm{U}_{\mathrm{e}}$ : product equilibrium water content (decimal dry basis). 
Experimental data were fit by four mathematical models: three nonlinear regression models, logarithmic (CHHINNAN, 1984), Thompson (THOMPSON et al., 1968), and Newton (LEWIS, 1921), and Wang's and Singh linear regression model (WANG \& SINGH, 1978). Parameters were estimated based on the Gauss-Newton iterative method, an algorithm based on minimizing the squared sum of the residuals. To check the quality of the models' fit to the experimental data, the adjusted coefficients of determination for the mean $\left(\mathrm{R}^{2}\right)$, the corrected Akaike Information Criterion (AIC) and the chi-square test $\left(\chi^{2}\right)$ were calculated and the model that presented higher $\mathrm{R}^{2}$ and lower AIC and $\chi^{2}$ values were selected to represent the drying kinetics data (FERNANDES et al., 2014). The selected model was used to produce the drying curve (RX x Time) and relative drying rate (TAS $\mathrm{x}$ Time) graphs. The absolute drving rate was obtained by the equation TAS $=\frac{\mathrm{M}_{\mathrm{t}+\mathrm{dt}}-\mathrm{M}_{\mathrm{t}}}{\mathrm{d}_{\mathrm{t}}}$

where:

$M_{t}=$ moisture at time $t ; \mathrm{M}_{\mathrm{t}+\mathrm{dt}}=$ moisture at time $t+d t$; and $d_{t}=$ time interval. It was also possible to infer changes in the drying process, indicating the moments of increased or decreased water loss. All analyses were performed using $\mathrm{R}$ ( R CORE TEAM, 2019).

\section{RESULTS}

The largest differences observed between sweet and typical pine nuts in the proximate composition analysis were in lipid and dietary fiber content, which were, respectively, 71 and $258 \%$ higher in sweet pine nuts both in natura and pine nut flour. Sweet pine nuts also had higher total and lower available carbohydrate content than typical pine nuts. Both sweet and typical pine nuts in natura showed no significant difference in ash content and protein, but these components were significantly higher in sweet pine nut flour when compared to typical pine nut flour (Table 1).

There were differences in additional parameters between the types of pine nuts. $L^{*}$ values were smaller for sweet pine nuts (Table 2), indicated by darker bars when compared to typical pine nuts. The highest $\mathrm{C}^{*}$ value was recorded in sweet pine nuts, as well as the lowest color purity (CHENG et al., 2018), and the highest $h$ values, indicating the darker hue of typical pine nuts.

Hardness did not vary significantly for the three positions within the sweet pine nuts. Overall, the typical pine nuts were harder than the sweet pine nuts and the hardness showed significant differences between three parts, decreasing from base to apex (Table 3).

Table 1 - Proximate composition of sweet and typical pine nuts in natura and pine nut flour.

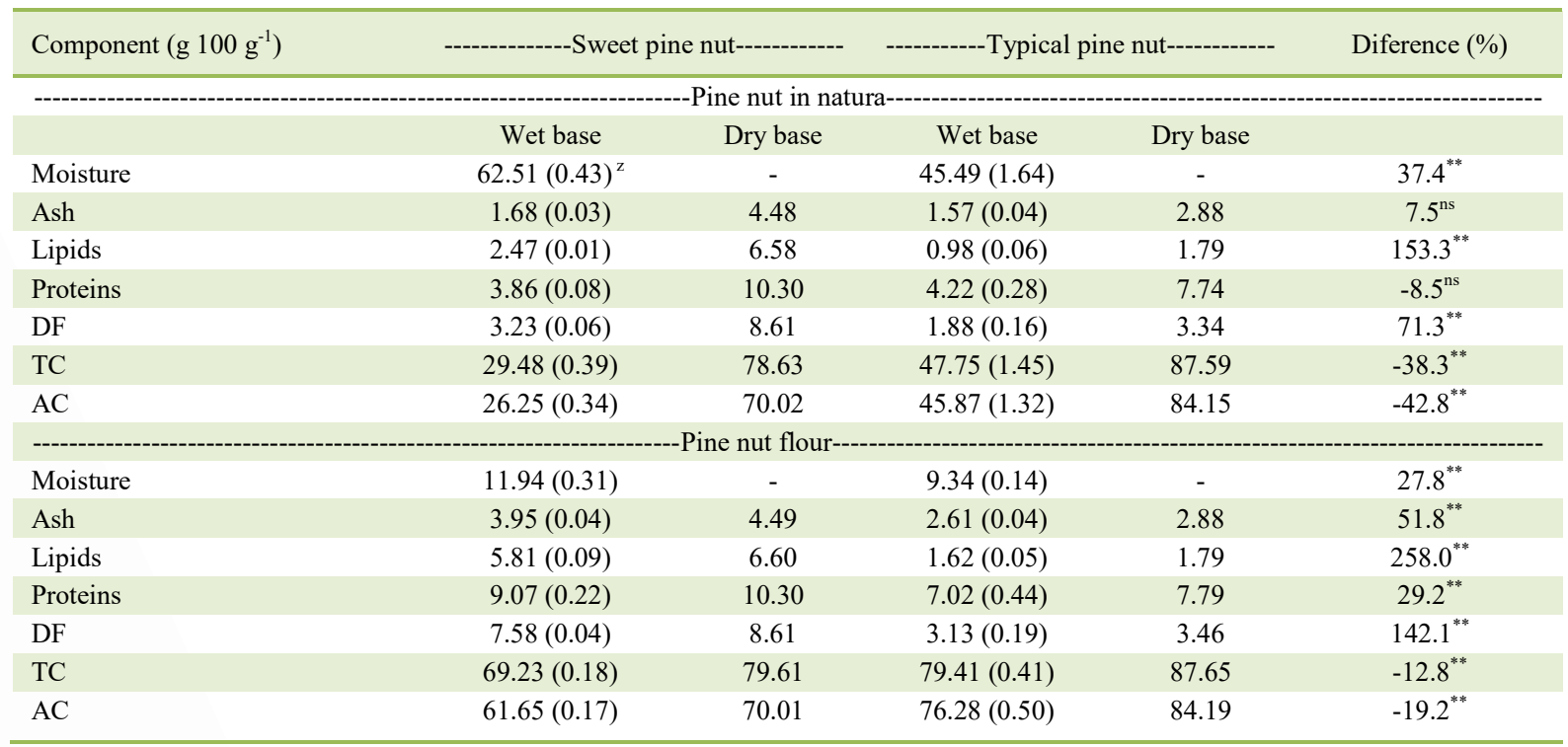

${ }^{\mathrm{z}}$ Average (standard deviation) $(n=3) .{ }^{\mathrm{ns}}$ non-significant and ${ }^{* *}$ significant difference by $t$-test $(P \leq 0.01)$, comparing sweet and typical (not sweet) araucaria nuts. DF: dietary fiber; TC: total carbohydrates; AC: available carbohydrates.

Ciência Rural, v.51, n.4, 2021. 
Table 2 - Coloring parameters of luminosity $\left(\mathrm{L}^{*}\right)$, chroma $\left(\mathrm{C}^{*}\right)$ and hue angle $(\mathrm{h})$ of sweet and typical pine nuts.

\begin{tabular}{lccc}
\hline Pine nut & $\mathrm{L}^{*}$ & $\mathrm{C}^{*}$ & $\mathrm{~h}$ \\
\hline Sweet & $80.0 \mathrm{~b}$ & $24.0 \mathrm{a}$ & $73.5 \mathrm{~b}$ \\
Typical & $84.6 \mathrm{a}$ & $15.4 \mathrm{~b}$ & $86.4 \mathrm{a}$ \\
$\mathrm{CV}(\%)$ & 5.2 & 16.2 & 5.4 \\
\hline
\end{tabular}

Means followed by distinct letters differ from each other by the Tukey test $(\mathrm{P} \leq 0.05)$.

In regards to the drying kinetics, among the four models evaluated to predict the pine nut drying phenomenon, the logarithmic and Thompson equations best fit the experimental data of moisture content reduction versus drying time. $\mathrm{R}^{2}$ values were higher than 0.98 in all pine nut cutting geometries, both in sweet and typical pine nuts, and in all three temperatures tested. Moreover, the AIC and $\chi^{2}$ test values were lower for these two models in all cases (three temperatures, two types of pine nut and three cutting geometries). In general, Newton's nonlinear regression also generated a good fit but had reduced efficiency in interpreting the drying results of the pine nut samples at $70{ }^{\circ} \mathrm{C}$. The smallest adjustments to the data were made using Wang and Singh's linear regression equation (Table 4). Thus, considering the three statistics (higher $\mathrm{R}^{2}$, lower AIC, and lower $\chi^{2}$ ) a graphical representation of drying kinetics of sweet and typical pine nuts can be made using either the Logarithmic or Thompson model.

Using the Logarithmic model, it was reported that higher temperatures promoted a reduction of drying time more significantly when the cutting geometry was more fractionated (transverse cuts in slices of $\sim 4.0 \mathrm{~mm}$ ) when compared to the other two longitudinal cuts which generated thicker slices. In order to reach $10 \%$ moisture, the seeds cut in thinner slices had reduced drying times at $50{ }^{\circ} \mathrm{C}$.
The sweet pine nuts took longer to dry ( 25 and $40 \mathrm{~min}$ for typical and sweet pine nut samples, respectively), which is explained by the higher initial moisture content, differences in chemical composition and structural conditions of the sweet pine nuts. No significant difference in drying time was observed between the type of slices at higher temperatures (60 and $70{ }^{\circ} \mathrm{C}$ ). When the seeds were cut in half, generating two thick pieces $(\sim 12.0 \mathrm{~mm})$, the drying time increased to $60 \mathrm{~min}$ at $70{ }^{\circ} \mathrm{C}$ (Figure 1).

In regard to the average relative rate of drying generated by the logarithmic model, the amount of water extracted per minute increased as temperature increased. This was especially true in sweet pine nuts, which have a higher initial water content. However, in the case of typical pine nuts, there was a significant increase in the drying rate when temperatures increased from 50 to $60{ }^{\circ} \mathrm{C}$, but when the temperature was increased from $70{ }^{\circ} \mathrm{C}$ the increase in drying rate was negligible (Figure 2).

\section{DISCUSSION}

In this research, for the first time, we compared the proximate composition between typical (non-sweet) pine nuts and sweet pine nuts, which have a sweet taste due to the greater reduction sugar content and total sugars (915\% and 466\%) and

Table 3 - Hardness (Newton) detected in different positions of sweet and typical pine nuts.

\begin{tabular}{lcr}
\hline Position of seed & Typical pine nut & Sweet pine nut \\
\hline Apex & $13.8 \mathrm{aC}$ & $10.0 \mathrm{bA}$ \\
Center & $21.9 \mathrm{aB}$ & $10.1 \mathrm{bA}$ \\
Base & $24.2 \mathrm{aA}$ & $10.0 \mathrm{bA}$ \\
CV $(\%)$ & -15.5 & \\
\hline
\end{tabular}

Means followed by distinct letters, uppercase in the column and lowercase in the row, differ from each other by the Tukey test (P $\leq 0.05$ ).

Ciência Rural, v.51, n.4, 2021. 
Table 4 - Adjusted coefficient of determination (R2aj) of equation, corrected Akaike Information Criterion (AICc) and chi-square test value $\left(\chi_{2}\right)$, for the four mathematical models analyzed during the pine nuts drying at $50 \mathrm{C}{ }^{\circ}, 60{ }^{\circ} \mathrm{C}$ and $70{ }^{\circ} \mathrm{C}$.

\begin{tabular}{|c|c|c|c|c|c|c|c|c|c|c|}
\hline & \multirow{2}{*}{$\begin{array}{c}\text { Sample } \\
\text { type }\end{array}$} & \multicolumn{3}{|c|}{ 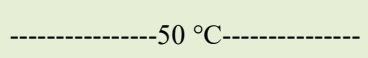 } & \multicolumn{3}{|c|}{ 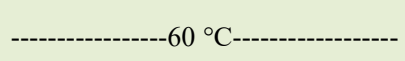 } & \multicolumn{3}{|c|}{ 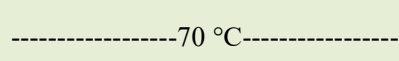 } \\
\hline & & $\mathrm{R}_{\mathrm{aj}}^{2}$ & $\mathrm{AIC}_{\mathrm{c}}$ & $\chi^{2}$ & $\mathrm{R}_{\mathrm{aj}}^{2}$ & $\mathrm{AIC}_{\mathrm{c}}$ & $\chi^{2}$ & $\mathrm{R}_{\text {aj }}^{2}$ & $\mathrm{AIC}_{\mathrm{c}}$ & $\chi^{2}$ \\
\hline \multirow{6}{*}{ Logarithmic } & 1 & 0.9947 & -139.17 & 0.00518 & 0.99634 & -158.27 & 0.00196 & 0.98170 & -190.98 & 0.00076 \\
\hline & 2 & 0.9989 & -185.99 & 0.01015 & 0.99827 & -181.53 & 0.00262 & 0.99852 & -311.81 & 0.00201 \\
\hline & 3 & 0.9918 & -126.21 & 0.00099 & 0.99743 & -169.24 & 0.00039 & 0.98989 & -219.48 & 0.00398 \\
\hline & 4 & 0.9972 & -158.67 & 0.00614 & 0.99712 & -165.69 & 0.00581 & 0.99849 & -310.72 & 0.00183 \\
\hline & 5 & 0.9912 & -124.13 & 0.00058 & 0.99601 & -155.64 & 0.00031 & 0.98221 & -192.33 & 0.00769 \\
\hline & 6 & 0.9965 & -151.50 & 0.00031 & 0.99664 & -160.98 & 0.00027 & 0.98686 & -206.88 & 0.00071 \\
\hline \multirow{6}{*}{ Newton } & 1 & 0.9881 & -117.28 & 0.00514 & 0.99182 & -135.58 & 0.00204 & 0.95043 & -145.28 & 0.00221 \\
\hline & 2 & 0.9982 & -174.52 & 0.00977 & 0.99754 & -172.88 & 0.00257 & 0.99572 & -262.89 & 0.00252 \\
\hline & 3 & 0.9829 & -106.45 & 0.00095 & 0.99652 & -162.10 & 0.00050 & 0.97385 & -175.98 & 0.00547 \\
\hline & 4 & 0.9944 & -140.09 & 0.00610 & 0.99635 & -160.62 & 0.00544 & 0.99600 & -266.12 & 0.00236 \\
\hline & 5 & 0.9825 & -105.90 & 0.00059 & 0.99192 & -135.96 & 0.00046 & 0.95563 & -150.60 & 0.00948 \\
\hline & 6 & 0.9941 & -138.35 & 0.00053 & 0.99447 & -147.72 & 0.00045 & 0.95892 & -154.30 & 0.00221 \\
\hline \multirow{6}{*}{ Thompson } & 1 & 0.9971 & -158.59 & 0.00511 & 0.99808 & -179.48 & 0.00191 & 0.99424 & -247.52 & 0.00017 \\
\hline & 2 & 0.9946 & -140.02 & 0.00934 & 0.99073 & -130.65 & 0.00233 & 0.99406 & -246.03 & 0.00098 \\
\hline & 3 & 0.9935 & -134.64 & 0.00130 & 0.99389 & -143.57 & 0.00039 & 0.99790 & -296.00 & 0.00326 \\
\hline & 4 & 0.9956 & -146.18 & 0.00595 & 0.98541 & -116.58 & 0.00504 & 0.99507 & -254.97 & 0.00095 \\
\hline & 5 & 0.9880 & -116.06 & 0.00088 & 0.99712 & -166.93 & 0.00034 & 0.99334 & -240.54 & 0.00684 \\
\hline & 6 & 0.9921 & -128.76 & 0.00070 & 0.99619 & -158.19 & 0.00031 & 0.99735 & -284.69 & 0.00014 \\
\hline \multirow{6}{*}{$\begin{array}{l}\text { Wang e } \\
\text { Singh }\end{array}$} & 1 & 0.8830 & -47.77 & 0.00785 & 0.82264 & -39.07 & 0.01072 & 0.51201 & -34.48 & 0.02600 \\
\hline & 2 & 0.8872 & -48.86 & 0.01281 & 0.84615 & -43.48 & 0.01184 & 0.54211 & -37.54 & 0.02684 \\
\hline & 3 & 0.9119 & -56.28 & 0.00473 & 0.88580 & -52.72 & 0.00978 & 0.70547 & -58.72 & 0.02780 \\
\hline & 4 & 0.8972 & -51.65 & 0.00922 & 0.81226 & -37.31 & 0.01458 & 0.64965 & -50.38 & 0.02603 \\
\hline & 5 & 0.9328 & -64.41 & 0.00462 & 0.87459 & -49.82 & 0.00971 & 0.72334 & -61.72 & 0.03107 \\
\hline & 6 & 0.9494 & -72.91 & 0.00450 & 0.88166 & -51.62 & 0.00969 & 0.51667 & -34.94 & 0.02599 \\
\hline
\end{tabular}

Sample type - 1 and 2: Typical and sweet pine nuts cut into slices of $\sim 4.0 \mathrm{~mm}$ thickness, respectively; 3 and 4: Typical and sweet pinion cut into a slice of the central part of the pinion, $\sim 8.0 \mathrm{~mm}$ thickness, respectively; 5 and 6 : Typical and sweet pine nuts cut into two longitudinal slices $\sim 12.0 \mathrm{~mm}$ thickness, respectively.

lower starch content $(54,8 \%)$ than typical pine nuts (SACHET et al., 2020). To date, sweet pine nuts have been detected in only one A. angustifolia matrix, which was used for seed collection by these authors and in the present research.

The appearance of sweet pine nuts may have arisen from the same physiological mechanism as that observed in sweet corn. A deficiency of enzymes responsible for the transformation of phytoglycogen into amylopectin dramatically reduces starch concentration and increases sugars (glucose, fructose, and sucrose) in sweet corn compared to typical corn (OLIVEIRA JÚNIOR et al., 2007). Compound levels detected in the proximate analysis of typical pine nuts in this research were within the range of variation previously reported to A. angustifolia pine nuts, both in fresh nuts and pine nut flour. Sweet pine nuts had higher minerals, lipids, proteins, and fiber, and lesser carbohydrates content than typical pine nuts (CORDENUNSI et al., 2004; CONFORTI \& LUPANO, 2008; SHIBATA et al., 2016; ZORTÉAGUIDOLIN et al., 2017).

Special emphasis is given to the fiber content of sweet pine nuts, as fiber contributes to nutrient metabolism and disease regulation (BRENNAN, 2005). This reveals the excellent nutritional value of sweet pine nuts, with its functional attributes and fewer calories $(140.2 \mathrm{kcal})$ compared to typical pine nuts ( $208.2 \mathrm{kcal})$. Special attention has been given to research on the nutritional use of starch-rich A. angustifolia seeds to promote the use of processed pine nuts (precooked, dehydrated, vacuum packed, etc.) or pine nut flour (after drying and milling) to make gluten-free bread and pasta (CORDENUNSI et al., 2004).

Coloration is a parameter that directly influences sensory analysis and consumer preference 


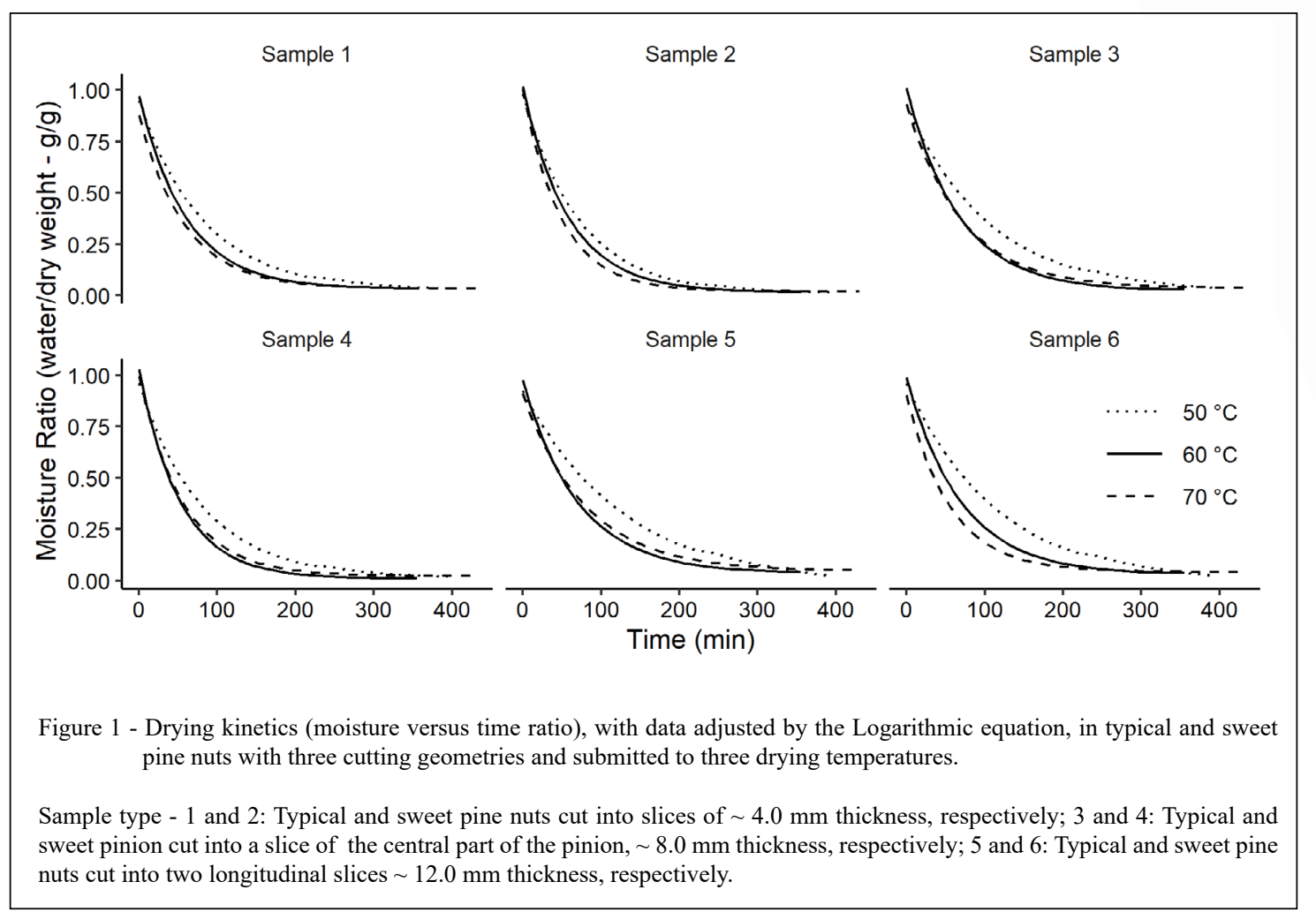

for food products. Sweet pine nuts presented $\mathrm{L}^{*}$ values of 80 which is lower than typical pine nuts $\left(\mathrm{L}^{*}=\sim 85\right)$, indicating a slightly darker hue; although, still close to white ( 0 indicates a totally dark color sample and 100 is an all-white sample) (MINOLTA, 1998; SPADA et al., 2012). The component that most influences color differentiation is sugar (GONÇALVES et al., 2014) and sweet pine nuts are so named because they have a higher total and reducing sugar content than typical pine nuts (SACHET et al., 2020). By evaluating hue (SPADA et al., 2012), we demonstrated the light pink color of sweet pine nuts and the light yellow of typical pine nuts.

The typical pine nut samples were harder than sweet pine nuts, which showed that it is necessary to use more force to compress and break the seed (GUSMÃO et al., 2018). The increased hardness in the base of the seed compared to the center and apex of typical pine nuts may be the effect of differences in proximate composition along the seed, verified by the higher starch and lower lipid content in the base as compared to the apex (COSTA et al., 2013). The greater softness detected in sweet pine nuts is explained by the lower starch content (SACHET et al., 2020), which should make it easier to cook and/or grind these pine nuts, which is advantageous for the production of flour and other derivatives in the food industry.

At $50{ }^{\circ} \mathrm{C}$, cutting the seed into several thin slices $(\sim 4.0 \mathrm{~mm})$ increased the evaporation rate of water due to increased surface area, resulting in decreased time to reach equilibrium moisture. Cutting geometry has been shown to influence the drying rate of tomatoes, because cutting them into four parts is more advantageous than cut in half (SANJINEZ-ARGANDOÑA et al., 2011). However, cutting pine nut slices requires more time to perform and when the temperature was raised to 60 and 70 ${ }^{\circ} \mathrm{C}$, there was no significant difference in drying rates between the three types of slices. The use of higher temperatures $\left(70{ }^{\circ} \mathrm{C}\right)$ increased the rate of water removal from sweet pine nuts, accelerating the drying process; this is due to the fact that a higher amount of heat transferred from the air to the material, with a consequent increase in the migration speed of the water within the pine nuts to the product surface (REIS et al., 2013). This considerably reduces the time required to reach equilibrium moisture, resulting in greater time savings compared to the use of lower temperatures $\left(50\right.$ or $\left.60^{\circ} \mathrm{C}\right)$. However, for typical pine nuts, the drying temperature of $60{ }^{\circ} \mathrm{C}$ can be used 


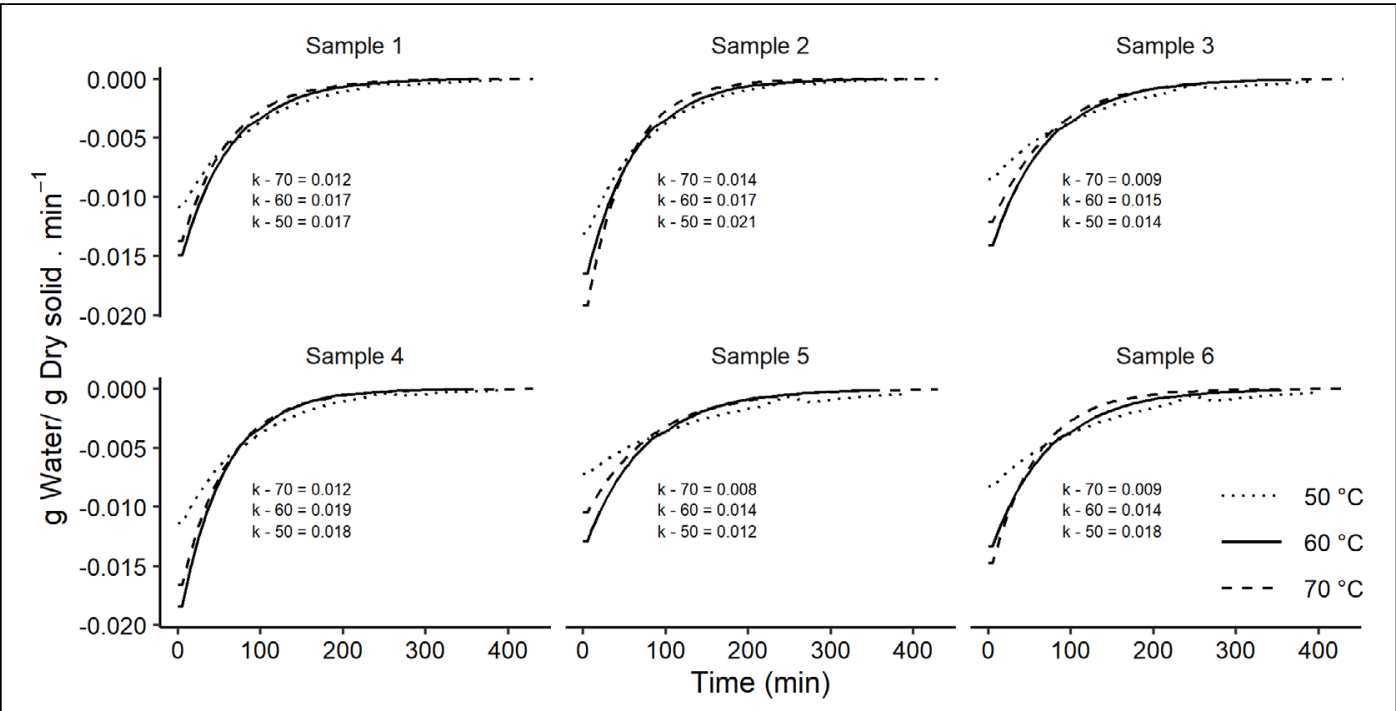

Figure 2 - Relative drying rate with data adjusted by the Logarithmic equation in typical and sweet pine nuts with three cutting geometries and submitted to three drying temperatures.

Sample type - 1 and 2: Typical and sweet pine nuts cut into slices of $\sim 4.0 \mathrm{~mm}$ thickness, respectively; 3 and 4 : Typical and sweet pinion cut into a slice of the central part of the pinion, $\sim 8.0 \mathrm{~mm}$ thickness, respectively; 5 and 6 : Typical and sweet pine nuts cut into two longitudinal slices $\sim 12.0 \mathrm{~mm}$ thickness, respectively.

since there was no increase in the drying rate from 60 to $70^{\circ} \mathrm{C}$. This generates energy savings for drying typical pine nuts.

The initial moisture content of the seed types ( 45.5 and $62.5 \%$ for typical and sweet pine nuts, respectively) influenced the time of drying. At $50{ }^{\circ} \mathrm{C}$, the typical pine nuts have been dried more slowly. This may be due to the fact that seeds with lower water content have higher binding forces between water molecules and require more energy to dry than those with a higher water content (AVIARA \& AJIBOLA, 2002). At $60^{\circ} \mathrm{C}$, the sweet pine nuts dried more slowly, probably due to the higher temperature being sufficient to accelerate the evaporation of water at the beginning of the drying process, but afterwards, the higher lipid content of sweet pine nuts may have acted as a limiting factor. Lipids, which are large nonpolar and hydrophobic molecules, may have acted as a physical barrier for heat transfer and limited the diffusion of water from the interior to the seed surface (REIS et al., 2018).

At $70{ }^{\circ} \mathrm{C}$, both the typical and sweet pine nuts dried at similar rates. If the drying process is not properly conducted, it can cause constituent losses (HO et al., 2016). However, in our research, the removal of water in preparation for flour production led to a product with a higher concentration of sugar. Therefore, dehydration under these conditions is a sound method of storage without loss of nutritional characteristics (FADIMU et al., 2018). The higher moisture and sugar content of the sweet pine nuts can reduce their preservation potential and accelerate their deterioration. Even for typical A. angustifolia seeds, due to their high water content, controlled drying is necessary to avoid the development of microorganisms (CONFORTI \& LUPANO, 2008). Processing Araucaria seeds to produce flour allows for off-season consumption (March to July).

The results of this research should be useful for the utilization of sweet pine nuts in the food industry, either to produce pre-cooked pine nuts or flour and can be used to make gluten-free breads and pastas. In addition to highlighting this type of pine nut for its sweet taste and soft texture, as already described in Sachet et al. (2020), the present study highlighted the greater nutritional potential of these pine nuts in relation to typical pine nuts. Sweet pine nuts have higher nutritional value than typical pine nuts, with higher lipid, dietary fiber, protein and ash content, lower total carbohydrate content and lower caloric value. Sweet pine nuts are also softer, which makes them easier to grind. 
We also delimit the best form of drying: thinner sliced pine nuts $(\sim 4.0 \mathrm{~mm})$ can be dried at a temperature of $50{ }^{\circ} \mathrm{C}$, while pine nuts thicker than $8.0 \mathrm{~mm}$ should be dried at a temperature of $60{ }^{\circ} \mathrm{C}$ for typical pine nuts and $70{ }^{\circ} \mathrm{C}$ for sweet pine nuts. The Logarithmic and Thompson models can be used to predict the drying kinetics of typical and sweet pine nuts in the temperature range of 50 to $70{ }^{\circ} \mathrm{C}$. To accelerate the drying rate, the pine nuts can be cut into thinner slices $(\sim 4.0 \mathrm{~mm})$ and dried at $70{ }^{\circ} \mathrm{C}$.

\section{ACKNOWLEDGMENTS}

BVG, APCM, MRS, MFR, and RHP thanks Brazilian agency CAPES (Coordenação de Aperfeiçoamento de Pessoal de Nível Superior) for fellowships. AR thanks CAPES, Fundação Araucária and Universidade Tecnológica Federal do Paraná (UTFPR) for postdoctoral fellowship. MAD thanks to Brazilian agency CNPq (Conselho Nacional de Desenvolvimento Científico e Tecnológico) for research fellowship.

\section{DECLARATION OF CONFLICT OF INTERESTS}

The authors declare no conflict of interest. The founding sponsors had no role in the design of the study; in the collection, analyses, or interpretation of data; in the writing of the manuscript, and in the decision to publish the results.

\section{AUTHORS' CONTRIBUTIONS}

BVG, APCM, MRS and MFR performed the experiments and carried out the lab analyses. MRS and RHP performed statistical analyses of experimental data. EAP and MAD conceived and designed experiments and supervised and coordinated the lab analyses. AR, EAP and MAD prepared the draft of the manuscript. All authors critically revised the manuscript and approved of the final version.

\section{REFERENCES}

AVIARA, N. A; AJIBOLA, O. O. Thermodynamics of moisture sorption in melon seed and cassava. Journal of Food Engineering, v.55, n.2, p.107-113, 2002. Available from: <https://doi.org/ doi:10.1016/S0260-8774(02)00023-7>. Accessed: Jul. 10, 2019. doi: 10.1016/S0260-8774(02)00023-7.

BITENCOURT, A. L. V; KRAUSPENHAR, P. M. Possible prehistoric anthropogenic effect on Araucaria angustifolia (Bert.) O. Kuntze expansion during the late holocene. Revista Brasileira de Paleontologia, v.9, n.1, p.109-116, 2006. Available from: <https://doi.org/doi: 10.4072/rbp.2006.1.12>. Accessed: Jul. 10, 2018. doi: 10.4072/rbp.2006.1.12.

BOLZAN, A. B.; PEREIRA, E. A. Preparation and characterization of a sweet creamy persimmon pudding with the addition of Brazilian pine seeds. Brazilian Journal of Food Technology, v.20, p.1-11, 2017. Available from: <http://dx.doi.org/10.1590/19816723.6116>. Accessed: Jul. 10, 2018. doi: 10.1590/19816723.6116 .
BRENNAN, C. S. Dietary fiber, glycemic response, and diabetes. Molecular Nutrition Food Research, v.49, n.6, p.560-570, 2005. Available from: <https://doi.org/10.1002/mnfr.200500025>. Accessed: Jul. 10, 2018. doi: 10.1002/mnfr.200500025.

CHENG, N. et al. Hunter versus CIE color measurement systems for analysis of milk-based beverages. Journal of Dairy Science, v.101, p.4891-4905, 2018. Available from: <https:// doi.org/10.3168/jds.2017-14197>. Accessed: Jun. 09, 2019. doi: 10.3168/jds.2017-14197.

CHHINNAN, M. S. Evaluation of selected mathematical models for describing thin-layer drying of in-shell pecans. Transactions of the American Society of Agricultural and Biological Engineers, v.27, p.610-615, 1984. Available from: <https://doi.org/10.13031/2013.32837> . Accessed: Jun. 09, 2019. doi: 10.13031/2013.32837.

CONFORTI, P. A.; LUPANO, C. E. Comparative study of the starch digestibility of Araucaria angustifolia and Araucaria araucana seed flour. Starch/Stärke, v.60, p.192-198, 2008. Available from: $<$ https://doi.org/10.1002/star.200600606>. Accessed: Jun. 09, 2019. doi: 10.1002/star.200600606.

CORDENUNSI, B. R. et al. Chemical composition and glycemic index of Brazilian pine (Araucaria angustifolia) seeds. Journal of Agricultural and Food Chemistry, v.52, n.11, p.3412-3416, 2004. Available from: <https://doi.org/doi:10.1021/jf034814l>. Accessed: Jun. 09, 2019. doi: 10.1021/jf0348141.

COSTA, F. J. O. G. et al. Characterisation of native starches of seeds of Araucaria angustifolia from four germplasm collections. Thermochimica Acta, v.565, p.172-177, 2017. Available from: <https://doi.org/10.1016/j.tca.2013.04.030>. Accessed: Jun. 09, 2019. doi: 10.1016/j.tca.2013.04.030.

DANNER, M. A. et al. Plantation of Brazilian pine to nuts production as a conservation tool. Pesquisa Florestal Brasileira v.32, n.72, p.441-451, 2012. Available from: <https:/doi. org/10.4336/2012.pfb.32.72.441>. Accessed: Jun. 09, 2019. doi: 10.4336/2012.pfb.32.72.441

ERTEKIN, C.; FIRAT, M. Z. A comprehensive review of thin layer drying models used in agricultural products. Critical Reviews in Food Science and Nutrition, v.57, n.4, p.701-717, 2017. Available from: <https://doi.org/10.1080/10408398.2014.910493 >. Accessed: Jun. 09, 2019. doi: 10.1080/10408398.2014.910493.

FADIMU, G. J. et al. Effect of drying methods on the chemical composition, color, functional and pasting properties of plantain (Musa parasidiaca) flour. Croatian Journal of Food Technology, Biotechnology and Nutrition, v.13, n.1-2, p.38-43, 2018. Available from: <https://doi.org/10.31895/hcptbn.13.1-2.2>. Accessed: Jun. 09, 2019. doi: 10.31895/hcptbn.13.1-2.2.

FERNANDES, T. J. et al. Selection of nonlinear models for the description of the growth curves of coffee fruit. Coffee Science, v.9, n.2, p.207-215, 2014. Available from: <http://www.sbicafe. ufv.br:80/handle/123456789/8029>. Accessed: Jun. 09, 2019. doi: $123456789 / 8029$.

GONÇALVES, P. M. et al. Characterization of starch nanoparticles obtained from Araucaria angustifolia seeds by acid hydrolysis and ultrasound. LWT - Food Science and Technology, v.58, n. 1, p.21-27, 2014. Available from: <https://doi.org/doi:10.1016/j. lwt.2014.03.015>. Accessed: Jun. 09, 2019. doi: 10.1016/j. lwt.2014.03.015. 
GUERRA, M. P. et al. Exploração, manejo e conservação da araucária (Araucaria angustifolia). In: SIMÕES, L. L.; LINO, C. F. Sustentável Mata Atlântica: a exploração de seus recursos florestais, São Paulo: SENAC, 2002, p.85-101.

GUSMÃO, R. P. et al. Technological characterization of cookies made with different concentrations of mesquite flour during 120 days of storage. Brazilian Journal of Food Technology, v.21, p.19, 2018. Available from: <https://doi.org/10.1590/1981-6723.11617>. Accessed: Jun. 09, 2019. doi: 10.1590/1981-6723.11617.

HO, L. H. et al. Effect of different drying conditions on proximate compositions of red- and yellow-fleshed watermelon rind powders. Journal of Agrobiotechnology, v.7, p.1-12, 2016. Available from: $<$ https://journal.unisza.edu.my/agrobiotechnology/index.php/ agrobiotechnology/article/view/100>. Accessed: Jun. 09, 2019.

INSTITUTO ADOLFO LUTZ. Métodos físico-químicos para análise de alimentos. São Paulo: Instituto Adolfo Lutz, 2008.

LEWIS, W. K. The rate of drying of solid materials. Journal of Industrial and Engineering Chemistry, v.13, n.5 p.427-432, 1921. Available from: <https://doi.org/10.1021/ie50137a021>. Accessed: Jun. 09, 2019. doi: 10.1021/ie50137a021.

MATHLOUTHI, M. Water content, water activity, water structure and the stability of food stuffs. Food control, v.12, n.7, p.409-417, 2001. Available from: <https://doi.org/10.1016/S0956-7135(01)00032-9>. Accessed: Jun. 09, 2019. doi: 10.1016/S0956-7135(01)00032-9.

MEGAZYME INTERNATIONAL IRELAND. Total dietary Fibre - Assay Procedure, Ireland: Megazyme, 2016.

MINOLTA CO LTD. Precise color communication: color control from perception to instrumentation. Osaka, 1998.

OLIVEIRA JÚNIOR, L. F. G. et al. Physiological differences between sweet corn (su-1) and maize during the development. Scientia Agraria, v.8, n.4, p.351-356, 2007. Available from $<$ https://doi.org/10.5380/rsa.v8i4.9879>. Accessed: Jun. 09, 2019. doi: $10.5380 /$ rsa.v8i4 9879

R CORE TEAM (2019) R: A language and environment for statistical computing. R Foundation for Statistical Computing, Vienna, Austria. Available from: <https://www.R-project.org/>. Accessed: Jan. 27, 2019.

REIS, D. R. et al. Drying kinetics of baru flours as function of temperature. Revista Brasileira de Engenharia Agricola e Ambiental - Agriambi, v.22, n.10, p.713-719, 2018 Available from: <https://doi.org/10.1590/1807-1929/agriambi. v22n10p713-719>. Accessed: Jun. 09, 2019. doi: 10.1590/18071929/agriambi.v22n10p713-719.

REIS, R. C. et al. Drying of yam starch (Discorea ssp.) and glycerol filmogenic solutions at different temperatures. LWT-Food Science and Technology, v.50, p.651-656, 2013. Available from: <https:// doi.org/10.1016/j.lwt.2012.07.033>. Accessed: Jun. 09, 2019.
SACHET, M. R. et al. Sweet endosperm detected in Araucaria angustifolia (Bertol.) O. Kuntze seeds. Genetic Resources and Crop Evolution, Published online on July 31, 2020. Available from: <https://doi.org/10.1007/s10722-020-00994-5>. Accessed: Aug. 01, 2020.

SANJINEZ-ARGANDOÑA, E. J. et al. Influence of temperature and geometry in the drying kinetic of tomato (Lycopersicum esculentum). Food Science and Technology, v.31, n.2 p.308312, 2011. Available from: <https://www.scielo.br/pdf/cta/ v31n2/v31n2a05.pdf $>$. Accessed: Jun. 09, 2019.

SHIBATA, M. et al. Physiological and physical quality of local Araucaria angustifolia seed variety. Acta Scientiarum. Agronomy, v.38, n.2, p.249-256, 2016. Available from: <https:// doi.org/10.4025/actasciagron.v38i2.27976>. Accessed: Jun. 09, 2019. doi: 10.4025 /actasciagron.v38i2.27976.

SPADA, J. C. et al. Study on the stability of $\beta$-carotene microencapsulated with pinhão (Araucaria angustifolia seeds). Starch, v. 89, n.4 p.1166-1173, 2012. Available from: $<$ https://doi. org/10.1016/j.carbpol.2012.03.090>. Accessed: Jun. 09, 2019. doi: 10.1016/j.carbpol.2012.03.090.

TEDESCO MJ, et al. Análises de solo, plantas e outros materiais. Porto Alegre: Departamento de Solos, UFRGS, 1995, 2ed.

IUCN. The IUCN Red List of Threatened Species. Version $2017-$ 3. 2018. Available from: <http://www.iucnredlist.org $>$. Accessed: Jun. 29, 2019.

THOMPSON, T. L. et al. Mathematical simulation of corn drying: a new model. Transactions of the ASAE, v.11, n.4, p.582-589, 1968. Available from: <https://www.ars.usda.gov/ARSUserFi les/30200525/34MathematicalSimulationofCornDrying.pdf $>$. Accessed Jun. 29, 2019.

WASZCZYNSKYJ, N., DA COSTA, F. J. O. G. Process of obtaining pine nut flour (Araucaria angustifolia). Titular: Universidade Federal do Paraná, BR 1020120152444 A2. Depósito: 20 jun. 2012. Concessão: 05 aug. 2014.

WANG, X. Q.; RAN, J. H. Evolution and biogeography of gymnosperms. Molecular Phylogenetics and Evolution, v.75, p.24-40, 2014. Available from: <https://doi.org/10.1016/j. ympev.2014.02.005>. Accessed: Jun. 09, 2019. doi: 10.1016/j. ympev.2014.02.005.

WANG, C. Y.; SINGH, R. P. Use of variable equilibrium moisture content in modeling rice drying. Transaction of ASAE, v.11, n. 78, p.668-672, 1978.

ZORTÉA-GUIDOLIN, M. E. B. et al. Influence of extrusion cooking on in vitro digestibility, physical and sensory properties of brazilian pine seeds flour (Araucaria angustifolia). Journal Food Science, v.82, n. p.977-984, 2017. Available from: <https://doi. org/ doi:10.1111/1750-3841.13686>. Accessed: Jun. 09, 2019. doi: 10.1111/1750-3841.13686. 